Мандриков, И.А. Ушаков // Теория и практика физической культуры. - 2016. - № 8. - С 37.

5. Мухамадиева А.А. Физическая культура и спорт как средства сохранения и укрепления здоровья студентов // Научное сообщество студентов XXI столетия. Гуманитарные науки: сб. ст. по мат. XXV междунар. студ. науч.-практ. конф. № 10(25). [Электронный ресурс]. - Режим доступа: http://sibac.info/archive/guman/10(25).pdf (дата обращения: 21.03.2017)

\title{
Миграция хлоридов в снежном покрове Центральной Якутии
}

\author{
Потапова С.А., аспирант, \\ Институт мерзлотоведения СО РАН им. П.И. Мельникова \\ E-mail: stellapotapova93@mail.ru
}

Научный руководитель: о.2.-м.н., профессор Макаров В.Н.

Центрально-Якутский комплексный геокриологический стационар «Туймаада» (КГСТ) располагается в Центральной Якутии на 2 надпойменной террасе p. Лены и представляет собой почти горизонтальную поверхность с альтитудой около 110 м.

Автором на территории КГСТ проведен мониторинг физических характеристик химического состава снежного покрова в период январь-апрель 2016 г. Пробы снега отбирались на ровной луговой площадке размерами 6х6 м в центральной части КГСТ. В 10 метрах от площадки мониторинга находится установка по сбору атмосферных осадков (рис. 1).

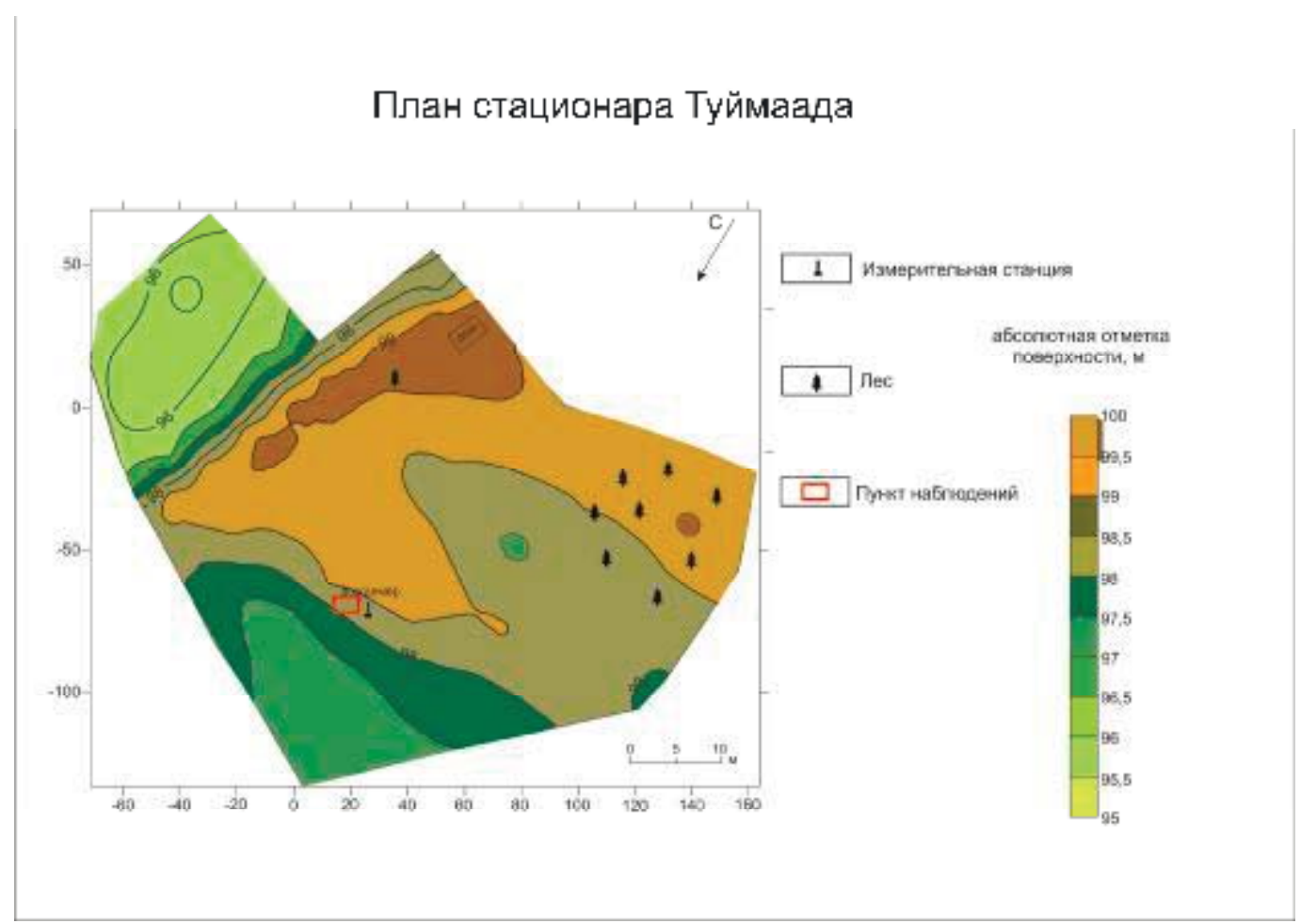

Рис. 1. Положение площадки мониторинга снежного покрова на КГСТ 
Пробы снега отбирались с интервалом 10 дней в период с 29 января до полного схода снежного покрова - 25 апреля. В пункте наблюдений измерялась высота и плотность снега, определялся водный эквивалент снежного покрова, измерялась температура воздуха и снега на поверхности и на почве.

Для периода мониторинга характерно постоянное уменьшение объёма выпадающих атмосферных осадков: февраль - 8,7, март - 5,1, апрель - 1,2 мм.

Температура воздуха в период мониторинга изменялась в диапазоне от минимальной $-44,5{ }^{\circ} \mathrm{C}$ (6 февраля) до $+14,5{ }^{\circ} \mathrm{C}$ (30 апреля). В этот же период температура снега на поверхности снежного покрова изменялась в диапазоне от $-39,4$ ${ }^{\circ} \mathrm{C}$ (20 января) до $+7,9^{\circ} \mathrm{C}$ (25 апреля).

Первое потепление с переходом температуры воздуха выше $0{ }^{\circ} \mathrm{C}$ наблюдалось 23-24 марта, когда температура воздуха повысилась до $+4,5{ }^{\circ} \mathrm{C}$. Постоянное потепление с переходом температуры воздуха в дневное время выше $0{ }^{\circ} \mathrm{C}$ (с 10 часов утра) установилось с 13 апреля. Температура снега на подошве снежного покрова в период мониторинга была несколько выше, чем на поверхности - в диапазоне от $-32,7{ }^{\circ} \mathrm{C}(29$ февраля) до $+0,1{ }^{\circ} \mathrm{C}$ (25 апреля). Разница температур на поверхности - подошве снежного покрова была максимальна в конце января - около $14{ }^{\circ} \mathrm{C}$, а в конце наблюдений составила $7,8^{\circ} \mathrm{C}$ (25 апреля).

Высота снежного покрова вследствие антициклонального режима погоды сравнительно невелика - 30-31 см, соответствует таковой в среднетаёжных ландшафтах - 29-45 см [3] и оставалась постоянной до 20 марта. Наступившее затем повышение температуры воздуха коррелирует с устойчивым снижением высоты снежного покрова до 16 см к 24 апреля.

Характерная особенность снежного покрова на участке мониторинга -

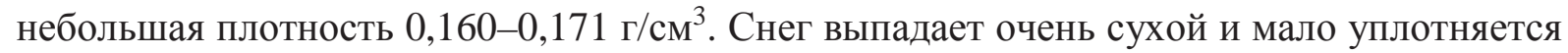

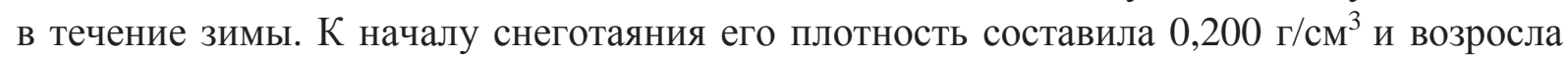
до 0,286 г/см в конце апреля.

Величина влагозапаса снежного покрова составляла 44-45 мм в конце января начале февраля и постепенно возрастала к середине марта, когда сформировались основные запасы воды в снеге, до максимальной величины - 61,2 мм и понизилась до 47 мм к времени активного снеготаяния - 25 апреля.

Влагозапас снега возрастал после выпадения осадков. Так, после продолжительного периода снегопада с 2 по 12 марта, когда выпало 4,3 мм осадков, влагозапас увеличился на 14,5 мм.

Концентрация пылевых частиц в снежном покрове на КГСТ незначительна 0,005-0,007 г/л.

По химическому составу снеговая вода в период мониторинга оставалась постоянно гидрокарбонатно-кальциевой ультрапресной, с диапазоном изменения минерализации в пределах одного порядка - 20,6-33,0 мг/л, в среднем около 25мг/л. Аномальное возрастание величины минерализации снега до 33 мг/л наблюдалось в первой половине марта после длительного снегопада со 2 по 12 марта.

Среднее содержание $\mathrm{Cl}^{-}$в период мониторинга составляло около 2,78 мг/л, минимальные установлены в конце января - 1,15 мг/л и в апреле - 1,1-2,0 мг/л. Максимальное содержание $\mathrm{Cl}^{-}-3,8$ мг/л (около 18\% от общего количества анионов в снеге) - наблюдалось после длительного десятидневного снегопада, когда с осадками увеличилось поступление солей морского происхождения (рис.2). 


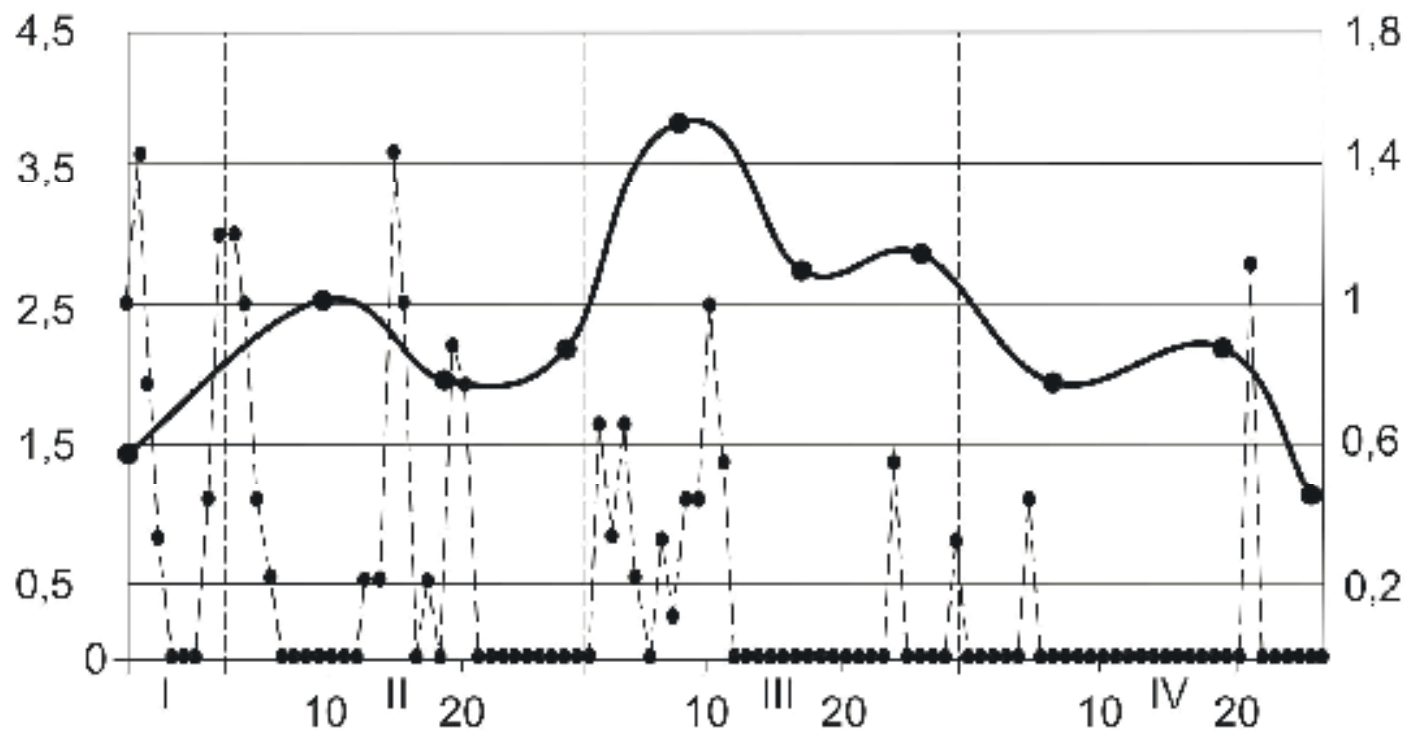

Рис. 2. Изменение содержания $\mathrm{Cl}^{-}$в снежном покрове и атмосферные осадки в период наблюдений

Сравнение с данными, полученными в 1996-2005 гг., показало, что среднее содержание $\mathrm{Cl}^{-}$в снежном покрове КГСТ в 2016 г. в два раза выше, чем было установлено ранее, что, возможно, связано с большим объёмом атмосферных осадков [2].

Плотность поступления химических элементов в снежный покров возрастает с конца января и достигает максимальных значений 16-17 г/м² в середине марта. Затем, до схода снега, наблюдается постоянное уменьшение плотности накопления химических элементов в снежном покрове до минимальных значений - 9,7 г/м ${ }^{2}$ в конце апреля (рис.3).

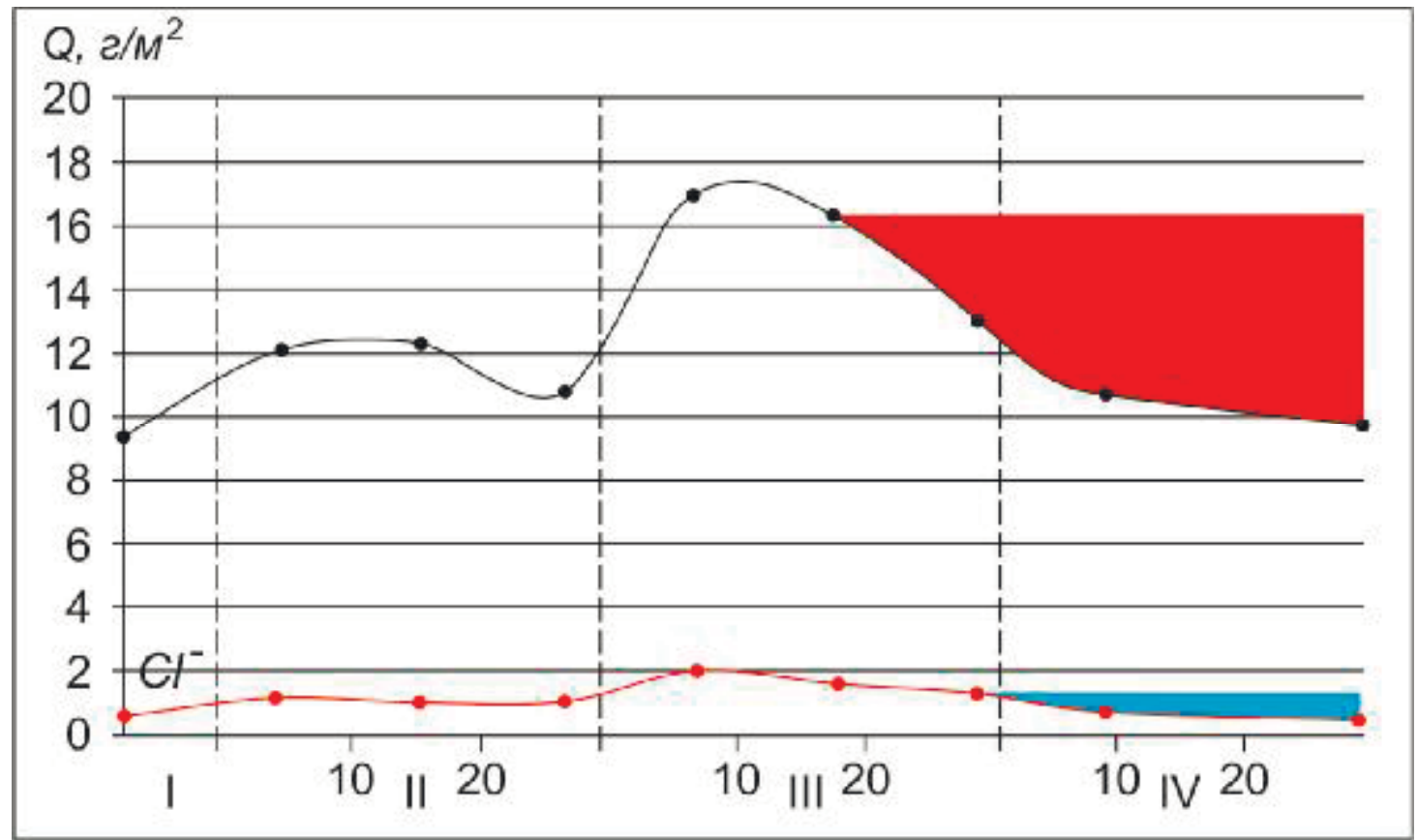

Рис. 3. Изменение плотности поступления солевого состава и $\mathrm{Cl}^{-}$в снежном покрове 
Аналогичные изменения характерны и для поступления хлора в снежный покров: плотность $\mathrm{Cl}^{-}$растет с конца января и достигает максимальных значений - 1,97 $\Gamma / \mathrm{M}^{2}$ в начале марта. Затем до схода снега наблюдается постоянное уменьшение плотности накопления хлора в снежном покрове до минимальных значений $-0,54$ г/м² в конце апреля (см. рис.3).

Активное таяние снега началось с переходом температуры воздуха в дневное время выше $0{ }^{\circ} \mathrm{C}$ (с 13 апреля), однако уменьшение плотности накопления хлора в солевом составе снежного покрова происходит ещё раньше - с конца марта - и продолжается до схода снега.

С 22 апреля наблюдается резкое повышение дневных температур на поверхности почвы до $-1,0{ }^{\circ} \mathrm{C}$ и переход через $0{ }^{\circ} \mathrm{C}$ уже через три дня - 25апреля. Переход дневных температур через $0{ }^{\circ} \mathrm{C}$ в почве на глубине 10 см произошел через десять дней с 3 мая.

Корреляционный анализ показал отсутствие значимых связей величины плотности $\mathrm{Cl}^{-}$в снежном покрове с температурой воздуха и снега на поверхности и на почве.

К 25 апреля, непосредственно к сходу снежного покрова, 30-75\% хлора были вымыты из снега. В тоже время водный эквивалент в снеге уменьшился только на $30 \%$.

Важно отметить, что в период разрушения и схода снежного покрова в начале мая почвенный покров остается мерзлым и основная масса влагозапаса снега и хлора перемещается в конечные водоёмы стока: городские озера и реку Лену.

В связи с аридным климатом в Центральной Якутии происходит засоление почв хлоридами [1]. Результатами исследований химического состава атмосферных осадков показано, что роль поступления $\mathrm{Cl}^{-}$с атмосферными осадками незначительна.

\section{Список литературы:}

1. Еловская Л.Г. Мерзлотные засоленные почвы Центральной Якутии. - М.: «Наука». - 1996. - С. 274.

2. Макаров В.Н. Геохимический мониторинг атмосферных осадков в Центральной Якутии. - Якутск: изд-во ин-та мерзлотоведения СО РАН. - 2007. - 88 с.: ил. 18, табл. 38.

3. Макаров В.Н. Геохимия снежного покрова таёжных и горных мерзлотных ландшафтов Якутии. - Лед и снег. - 2014. - № 1 (125) - С.73-80. 